Abalde-Cela, S. 466

Batista, I.A. 479

Bellevicine, C. 497

Clery, E. 497

Costa, J.L. 448, 456, 479

Diéguez, L. 466

Fernandes, G. 456

Fernandes Marques, J. 456

Hespanhol, V. 456

Junqueira-Neto, S. 479
Machado, J.C. 456

Malapelle, U. 489, 497

Massias, J. 449

Melo, S.A. 479

Pereira Reis, J. 456

Piairo, P. 466

Pisapia, P. 489, 497

Poulet, G. 449

Schmitt, F.C. 448,497

Taly, V. 449

Troncone, G. 489, 497

Vigliar, E. 497

\title{
Subject Index Vol. 63, No. 6, 2019
}

Biomarker(s) 449, 456, 479

Cancer 449, 456, 479

- prognosis 466

CellSearch $^{\circledR} 466$

Circulating cell-free DNA 449

- mRNAs/miRNAs 479

- tumor cells 449, 466

- _ DNA 449, 456, 489

Digital polymerase chain reaction 489

Disease monitoring 456

EGFR 489

Epithelial-mesenchymal transition 466

Exosomes 479

Liquid biopsy 449, 456, 466, 479, 489

Lung cancer 489,497
Molecular pathology 497

Morphological transition 497

Mutation detection 456

Next generation sequencing 489

Non-small cell lung cancer 489, 497

Personalized medicine 466, 489

Platelets 479

Quantitative polymerase chain reaction 489

Sequencing 456

Tyrosine kinase inhibitors 497 